\title{
Teachers' Perceptions of the Dimensions of the Psychosocial School Environment in Primary Schools in Trinidad and Tobago
}

\author{
George Gowrie ${ }^{1}$, Mala Ramdass ${ }^{2}$ \\ ${ }^{1}$ The University of Trinidad and Tobago, Trinidad and Tobago \\ Received: September 2, 2014 Accepted: September 10, 2014 Online Published: September 24, 2014 \\ doi:10.11114/jets.v2i4.524 \\ URL: http://dx.doi.org/10.11114/jets.v2i4.524
}

\begin{abstract}
The study explored some of the important psycho-social factors in the primary school environment that impact on students' learning as perceived by teachers. It also attempted to identify, describe and develop conceptual categories as separate dimensions of the social and emotional environment.

The sample consisted of 187 teachers and 53 schools selected from one Educational District - St. George East. The data were analyzed using the Statistical Package for the Social Sciences (SPSS-SPG2). Statistical means, T-tests, ANOVA and regression analysis were used to make comparisons between schools and to show the relationships between the independent psycho-social categories and the overall dependent psycho-social environment. The five independent psychosocial categories were teacher-student relations, teacher-related issues, student and curriculum issues, school organization and policy and school health and safety.

The findings revealed that teachers perceived student-related and school violence issues as the most important dimensions of the psychosocial environment. There was a significant positive correlation between the five dimensions of the psychosocial environment. Also, the psycho-social environment had negative influences on students' attitudes and emotional well-being as perceived by teachers in many of our primary schools in the sample, especially in the Government schools. The findings further indicated that teacher-related issues had the greatest influence on the overall psycho-social environment.
\end{abstract}

Keywords: healthy psychosocial environment, teacher-related issues, teacher-student relations, student and curriculum issues, school organization and policy

\section{Background}

Primary schools in Trinidad and Tobago have their roots in the mid-nineteenth century. During this period, the intense rivalry between State and Church, Church and Church, led to Church-controlled and State-controlled schools. In this 'dual' arrangement, the Church-run or denominational schools exercised power in the management of these schools and the appointment of personnel. To this day, the 'dual' system is still a central feature of our education system, with the government-assisted or denominational schools having an input in the appointment, promotion and transfer of principals and teachers (The Concordat of 1960).

At present, there are approximately 600 primary schools in eight (8) Education Districts in Trinidad and Tobago. These schools are divided into government and government-assisted schools. The government-assisted schools include Catholic, Hindu, Muslim, Anglican, Seventh - Day Adventist, Presbyterian and Moravian schools.

The primary system is a centralized one, whereby, all schools are governed by a central authority headed by a Minister of Education, who has overall responsibility for the general organization of schools. The Minister is assisted by a Permanent Secretary, a Chief Education Officer and other technical directors.

All primary schools follow a common curriculum and have the common objective of preparing students for secondary education. There is a common examination, the Secondary Entrance Assessment (SEA) which facilitates this process of secondary school selection.

Teachers at the primary level are general practitioners, that is, each teacher is expected to teach all the subjects on the prescribed syllabus for primary schools. While many teachers in the primary school system possess the two year Teachers' Diploma, the present requirement to teach in primary schools is the four-year Bachelor of Education. As a result, all teachers in the system are required to pursue the four-year degree programme while all incoming 
student-teachers must pursue the four-tear degree to be eligible to teach in primary schools.

\section{Introduction}

There is increasing recognition that health and educational outcomes are inextricably linked, and that the school can be an ideal setting through which to strive for both (Gadeyne \& Onghena, 2006). The literature on school health has shown that schools contribute to a student's positive adjustment when they function as psychologically healthy environments for development (Baker,Dolly, Aupperlee \& Patil, 2003; Knuver \& Brandsma, 1993). Schools, therefore, are important contexts for children's development because of the time children spend there, the degree to which they influence children's experiences and self perceptions and their potential to affect their life chances (Baker et al, 2003).

A number of international efforts have been developed in the past decade to improve both learning and health through schools. For example, the Dakar Framework for Action (UNESCO, 2000) promotes a school environment that not only encourages learning but is gender-sensitive, healthy and safe. The World Health Organization (WHO), through its global school health initiative, promotes the concept of a Health-Promoting School as one which constantly strengthens its capacity as a healthy setting for living, learning and working. Such a school provides a psycho-social environment to improve the health of school personnel, families, parents, students and the wider community. UNICEF has also developed a framework to help school personnel assess qualities of the school environment that support social and emotional well-being and a learning environment in which boys and girls are motivated to learn (Shaeffer, 1999).

In the Canadian experience health experts have developed an evidence-based school health instrument (Healthy School Report Card) which is a self-assessment process based on research and best practices across Canada related to healthy whole-school environment. This school health instrument is a practical mechanism in which schools coordinate school, parents and community stakeholders to assess, identify and prioritize the changes that schools can make to improve the psycho-social and physical health of its community through systemic changes (Vamos, 2006).

In the context of Trinidad and Tobago, while some of our schools exhibit healthy characteristics, the state of health of many of our primary schools has been described as 'organizational pathologies' with poor teacher motivation, student indiscipline, a lack of effective leadership and low levels of academic achievement (Ministry of Education, Policy Paper 1993-2003). So critical is the situation that the Ministry of Education commissioned a study on delinquency in schools that identified an alarming increase in school violence and delinquency such as bullying, truancy, verbal abuse to teachers, gang warfare and fighting with weapons (Deosaran, 2004). The Ministry of Education has embarked on numerous initiatives to develop a culture of peace and civility in our schools. Some of these initiatives are Peace Promotion Programmes, Safety Officers, Student Support Services, School Feeding Programmes and improved homeschool linkages. A recent study of the state of health on one of the largest Education Districts in Trinidad and Tobago revealed that school health is not a priority by school administrators and many of our primary schools are lacking in basic health facilities such as inadequate physical conditions, lack of administrative support and little attention to the emotional and social needs of children (Gowrie, Ramdass, Bowrin \& Alleyne 2009).

\section{Assumptions of the Study}

There are several assumptions upon which this psycho-social environment study is based. Firstly, it is possible to identify and measure, to some degree, the psycho-social school environment as perceived by teachers. Secondly, the psycho-social school environment has influences on student's learning and the overall school climate, teaching and learning environment.

\section{Level of Analysis}

The study was guided by the works of Sirotnik (1980) who advocates the group as the unit of analysis. Furthermore, many school climate and health studies have used the group as the appropriate unit of analysis (Kershaw, Blank \& Brian, 1994). In this study, therefore, individual perceptions were aggregated across individuals to arrive at a school score. The level of analysis was the school and not the individual.

\section{Delimitation}

The study recognizes that there are a multiplicity of variables that make up a school's psycho social environment. It would have been ideal to include the perceptions of all stakeholders - teachers, students, administrators, supportive staff and parents in the study. However, since teachers are the primary means by which school goals are attained (Mac Phail-Wilcox \& Hyler, 1988), and, given the infancy stage and exploratory nature of the study, it was more practical to focus on teachers.

\section{Literature Review}

The study was guided by the psychological literature to help develop a framework to get a deeper understanding of the psychosocial environment of our primary schools. The increasing incidents of school violence, student indiscipline, 
weak leadership and teacher absenteeism have focused more attention on the social, emotional and psychological environment of our primary school system. The literature on child and adolescent learning needs and motivation theories has provided useful insights into the psychological environment of our schools and how such environment shapes the development of children and contribute to their to their positive adjustment (Baker et al 2003., Knuver and Brandsma, 1993).

The literature on the psycho-social environment of schools posits that schools contribute to students' positive adjustment and sense of well-being when they function as psychologically healthy environments for development (Baker et al, 2003; Nutbeam, Smith, Moore \& Bauman, 2008). Gadin \& Hammarstrom (2003) analyzed the effects of psycho-social factors on pupils' health and self worth from a longitudinal perspective. They found that a negative development of psycho-social factors at school was associated with poorer health and self worth among pupils.

Positive teacher-student relationships are important in providing a supportive school environment that can have a positive effect on the mental health and well-being of students (Havlinova \& Schneidrova, 1995). Research studies in Australia and the United Kingdom have shown that factors like relationships between teachers and students in classroom opportunities for student participation and responsibility and support structures for teachers have consistently shown to be associated with student progress (Patton, Glover, Bond, Butler, Godfrey, Peitro \& Bowles, 2000). Other research studies have further examined the extent to which psycho-social outcomes in primary school children vary between classes, and whether elements of teaching can explain some of the variation. Their findings suggested that teaching variables seemed to explain more of the variance in psycho-social adjustment and emphasized the importance of psycho-social effectiveness for teaching (Gadeyne et al, 2006).

There is a growing body of research that indicates that a strong sense of teacher efficacy is an important attribute that provides teachers with continuing motivation and dynamism that helps to nurture and develop a positive school climate and psycho-social environment that enhance student learning, especially for low-achieving students (Coladarci, 1992; Guskey, 1998). Additional studies have further emphasized the importance of both novice and experienced teachers' interaction with students as they provide guidance through observation of classroom lessons, team teaching, coaching and reflective practice (Onafowora, 2004). These skills contribute to the development of a strong sense of social and emotional relational base that support students' commitment to learning.

Research on health behaviours of school-age children has shown that risk and health factors such as lack of daily care, diet, substance abuse and delinquent behaviour have a negative impact on the psycho-social and physical school environment that impede student positive outcomes. The studies examined relationships between students' sense of the school as a community and the prevalence of problem behaviours among fifth and sixth graders in a diverse sample of primary schools in the U.S.A. The findings revealed that schools with higher average sense-of-community scores had significantly lower average drug use and delinquency (Cartland \& Ruch-Ross, 2006).

Increasing incidents of school violence also threaten the mental health of pupils. Exposure to violence at school is associated with significant self-reported psychological trauma symptoms and violent behavior (Flannery, Waster \& Singer, 2004). A case study by Finley (2003) on school violence highlighted some critical concerns at the school level that must be addressed when trying to understand school-based violence. The findings indicated the need for schools to provide a caring and supportive environment that enhances the social and emotional well-being of students. Other studies have highlighted further the impact of school safety and violence on the psycho-social environment of schools. Sprague, Nishioka \& Smith (2007), in their study of three communities in Oregon, U.S.A. found that factors such as positive behaviour supports and the establishment of school-based mental health services improve the social and emotional school environment. Supportive studies on the school's social and emotional environment have found a strong relationship between exposure to violence at school and psychological trauma systems (Flannery et al, 2004; Morrison, Furlong and Morrison, 1994; Stephens, 1994) as well as the important role teachers and other stakeholders play in creating a healthy school environment to control violence and aggression (Bauman, 2008; Finley, 2003; Barth, Dunlap, Dane, Lochman \& Wells, 2004).

Research in many countries has further indicated that school structure, policies, and organization also have a profound impact on the school's psycho-social environment and student outcomes. The Gatehouse Project in the Australian context highlighted the impact of school organization and policies on the emotional well-being of students (Bond, Butler, Glover, Godfrey \& Patton, 2001). The Project focused on building the capacity of school structures and processes to address the emotional and mental needs of students to enhance a sense of connectedness among them. The research also provided a conceptual whole-school approach that identified priority areas for schools to develop new structures, policies and practices to promote and enhance the school's psycho-social environment. One of these priority areas was the need to have a more dynamic relationship between the home, community and the school (Henderson, 1998; Ryan, 2002). 
Such inter-connectedness between the home and the school has been one of the major features of the World Health Organization's 'Health Promoting School' international thrust to ensure that all stakeholders play a key role in creating a positive physical and emotional environment in schools (WHO, 2000). Supportive research (Griffith, 1998; Vamos, 2006) has also affirmed that students' emotional well-being was high when school policies, organization and effective leadership encouraged parental engagement in schools.

Consistent with the research on the importance of school structure and policies in influencing students' well-being other studies have shown that traditional health education programmes are insufficient to promote students' healthy life styles. Nutbeam et al, 1993 have pointed out that most of our schools need to transform their ethos and structures so that students will not feel alienated from others and the school as a whole. Indeed, Olweus (2003) found that such 'alienation' increased bullying behavior and other aggression among students in a sample of primary schools in Australia. They found that bullying behavior was associated with increased psychosomatic symptoms. Students who bullied and were bullied had the greatest number of psychological imbalances.

Other health studies have also noted that the school's physical environment (Tanner,2008), the design patterns of school such as poor lighting and ventilation, lack of security and excessive noise(Fuller, Dauter, Hosek, Kirshenbaum, Mckoy, Rigsby \& Vincent 2009; Uline \& Tschannen-Moran, 2007) have negative influences on students' attitudes and emotional well-being.

In Trinidad and Tobago, studies on the state of health of a sample of primary and secondary school (Deosaran, 2004; Gowrie et al, 2009) found that there were inadequate facilities, lack of health policies and weak school -community linkages. Many of the schools, especially the Government schools, had a high incidence of alcohol abuse, bullying and gang warfare.

\section{Research Questions}

The following research questions guided the study:

1. Which schools in the sample were considered to exhibit high and low psychosocial dimensions as perceived by teachers?

2. Were there differences in each of the five psychosocial dimensions based on school type, location, gender and school size?

3. What was the nature of the relationship between each of the psychosocial dimensions?

4. Which psychosocial dimensions had the greatest influence on the overall dependent psychosocial environment?

The study was a quantitative research using a cross-sectional design to test hypotheses and show relationships between variables. The survey technique was also employed as it allowed the researcher to examine psychosocial categories individually and their correlations with each other. It also allowed for some generalizations to emerge with more confidence than would not otherwise be possible (Creswell, 2008).

\section{Method}

The questionnaire was adapted from the World Health Organization (WHO) world -wide studies on the social and emotional environment in primary schools. The items were derived from a systematic review of evidence from more than 650 articles in the international literature and were reviewed by schools in 20 countries world-wide (Skevington \& Puitandy, 2002 in WHO/FHE, 2003). A pilot study was conducted in a randomly selected sample of 10 primary schools and sixty teachers to ascertain any ambiguities and the contextual relevance of the items. The sample of teachers in the pilot was of the view that the items were clear and culturally relevant.

The questionnaire consisted of 74 items that measured five dimensions of the psychosocial environment. A 5-point Likert rating scale was employed that ranged from Strongly Disagree to Strongly Agree.

Questionnaire description

Sample

The school sample for the study was selected from the target population of all government and government assisted schools in the St. George East Education Division (88 schools). The researcher considered the St. George East Education Division appropriate for the study since there was a wide range in the distribution of different school types. A revised (2011) listing of these schools was obtained from the Planning Division of the Ministry of Education. Random sampling with a disproportionate selection of schools was used to select the sample. Given the wide variation in size and types of schools in this division, sample components were made disproportionate to avoid under representation of Government and Government -Assisted schools (Borg \& Gall, 2000). Fifty-four (53) schools were randomly selected to ensure that all 
schools had an equal chance of selection.

The teacher sample consisted of 187 randomly selected teachers with over 10 years of experience from the fifty three (53) school types representing government, government-assisted (Christian and non- Christian) schools. The Christian schools comprised the Roman Catholic, Presbyterian and Adventist schools while the non -Christian schools comprised the Hindu and Muslim schools. The names of these teachers were obtained from the schools' teacher registers (Table1). The sample consisted of 17 government schools and 74 teachers; the Roman Catholic schools consisted of 12 schools and 38 teachers; the other Christian schools consisted of 11 schools and 35 teachers and the non-Christian schools consisted of 11 schools and 40 teachers (Table1).

Table 1. Sample of School Type, Number of Selected Schools and Teachers

\begin{tabular}{lcc}
\hline School Type & Number of Selected Schools & Number of Teachers \\
\hline Government & 17 & 74 \\
Roman Catholic & 12 & 38 \\
Other Christian & 11 & 35 \\
Non-Christian & 13 & 40 \\
Total & 53 & 187 \\
\hline
\end{tabular}

The variables of urban, rural, small and large were considered important and taken into account in the study. The term 'rural' cannot be precisely defined nor cannot be strictly demarcated when compared to its urban counterpart (Semke \& Sheridan, 2011). Indeed, the notion of rural-urban has shifted from the traditional idea of a dichotomy to that of a continuum (Chomitz, Buys \& Thomas, 2005). Chomitz et al (2005) assert that two dimensions of this continuum are population density and remoteness from large metropolitan areas. According to the Food and Agricultural Organization (2005) the term 'rural' should meet two criteria which are low population density and a dependence on primary production activities as a source of livelihood. In the Trinidad and Tobago context, the Central Statistical Office (2009) classified a rural community based on the prevalence of a high level of agricultural activity and remoteness from the main urban areas. For the purposes of this study, 'urban' is defined as clustered settlements with a high degree of commercial/industrial activity and 'rural' is defined as dispersed settlements with some form of agricultural/pastoral activity.

The identification of small and large schools follows the guidelines of the Planning Unit, Ministry of Education. Schools with less than 250 students and no appointed vice-principal were deemed small, while schools with 500 and more pupils were viewed as large.

\section{Questionnaire Description}

The questionnaire consisted of two sections. The first section elicited demographic data from respondents such as gender, school type, size and location. Such data were important to answer research questions and test hypotheses based on these characteristics. The second section consisted of 55 psycho-social statements. Teachers were asked to rate the extent to which each statement was true of their school by responding to each item along a four- point Likert -type scale ranging from 'not at all' to 'very much'. The 55 items that were subdivided into five categories: teacher -related issues, student and curriculum issues, teacher-student relationships, school health and safety issues, and school organization and policy issues.

There were 11 items relating to teacher-related issues. Teacher -related issues involved teacher efficacy, teacher-teacher relations, a sense of safety and belonging to the school and teaching strategies that relate to students' needs and interest. For example: staff has a strong sense of belonging to the school; teachers are confident that they will receive help and support from other staff when they need it.

There were eight items relating to student and curriculum issues. Student and curriculum issues dealt with student -student relations, students' sense of belonging to the school, student behaviors such as bullying and aggression, students approach to school work and student safety and security. For example: students are concerned about what happens to each other; students spend time working together to solve problems.

There were six items relating to teacher-student relationships. This category focused on teacher support for students, students trust in teachers and student and teachers working together. For example: students know that they can seek help from staff when they are bullied; teachers organize students for group activities so they can work together.

There were six items relating to the school violence, discipline and safety category. This category focused on school discipline and safety issues such as bullying, aggressive student behaviour and the enforcement of school discipline procedures. For example: the school discipline rules are clear to everyone; students feel safe at school. 
There were 24 items relating to school organization and policy. This category was the largest and focused on the school's physical and social environment, school policies regarding school violence, bullying and other forms of aggressive behavior, school-community relations, school leadership and school structures that support teachers and students to ensure a safe and healthy environment. For example: those in charge are seen as fair and consistent; school policies for dealing with violence and aggression are enforced; parents are encouraged to be supportive of the school and governance.

\subsection{Data Analysis and Findings}

Questionnaire responses were quantitatively analyzed through the use of appropriate statistical tools such as means, t-tests, analysis of variance (ANOVA), and regression analysis using the Statistical Package for the Social Scientists (SPSS-SPG2).

Research Question 1: Which schools in the sample were considered to have high and low psychosocial dimensions as perceived by teachers?

\section{(i) Overall psychosocial environment}

This part of research question 1 attempted to identify the number of schools with high and low psychosocial environments. It was, therefore, necessary to establish a cut-off point to establish which schools could be considered high and vice versa. This was done by using the overall mean (2.75). Schools with their mean score of 2.75 and above were considered high and schools with less than 2.75 were considered low. There were seven schools $(\# 5,15,31,33,34$, $42,48)$ with the highest mean scores above the mean. There were five schools $(\# 4,16,23,45,51)$ with the lowest mean scores below the mean (Table2).

(ii) School organization and policy.

Eight schools $(5,15,31,33,34,42,48)$ exhibited the highest psychosocial environment while five schools $(\# 4,16,23,45,51)$ scored the lowest below the mean score in this category (Table2).

\section{(iii) School violence, Discipline}

Five schools $(\# 5,15,33,34,48)$ scored the highest above the mean while five schools $(\# 4,13,19,23,53)$ scored the lowest below the mean in this category (Table2).

\section{(iv) Teacher-student Issues}

Ten schools (\#15,26,31,33,34,35,40,41,4243) scored the highest above the mean while seven schools (\#4,10,13,23,45,47,51) scored the lowest below the mean in this category (Table2).

\section{(v) Student and Curriculum Issues.}

Six schools $(\# 5,15,33,38,42,49)$ scored the highest above the mean while six schools $(\# 4,8,14,23,32,51)$ scored the lowest below the mean in this category (Table2).

Table 2. Schools with the Highest and Lowest Mean Scores on the Overall and on Each Psychosocial Category

\begin{tabular}{|c|c|c|}
\hline Psychosocial Category & Highest Mean Score & Lowest Mean Score \\
\hline $\begin{array}{l}\text { Overall psychosocial environment } \\
(\text { mean }=2.75)\end{array}$ & $\# 5,15,31,33,34,42,48$ & $\# 4,16,23,45,51$ \\
\hline $\begin{array}{l}\text { School organization and policy } \\
(\text { mean }=2.46)\end{array}$ & $\# 5,15,31,33,34,42,48$ & $\# 4,16,23,45,51$ \\
\hline $\begin{array}{l}\text { School violence and Discipline } \\
(\mathrm{mean}=2.84)\end{array}$ & $\# 5,15,33,34,48$ & $\# 4,13,19,23,53$ \\
\hline $\begin{array}{l}\text { Teacher-student Issues } \\
(\text { mean }=2.84)\end{array}$ & $\# 15,26,31,33,35,40,41,42,43$ & $\# 4,10,13,23,45,47,51$ \\
\hline $\begin{array}{l}\text { Student and curriculum Issues } \\
(\text { mean }=2.73)\end{array}$ & $\# 5,15,33,38,42,49$ & $\# 4,8,14,23,32,51$ \\
\hline $\begin{array}{l}\text { Teacher-related Issues } \\
(\text { mean=2.71) }\end{array}$ & $\# 9,15,31,33,42,49$ & $\# 4,16,23,53$ \\
\hline
\end{tabular}

It was noted that those schools $(\# 5,1526,31.33,34,42,48,49)$ with the highest mean scores were government-assisted, while those schools $(\# 4,16,19,23,45,47,51)$ with lowest mean scores were government schools. 
Research Question 2: Were there differences in each of the psychosocial dimensions based on school type, location, gender and school size?

2(i) Significant differences between each of psychosocial dimensions in Government and Government -assisted schools There were significant differences in three of the PSE categories: teacher -related issues, teachers-student issues and school policy and organization (Table 3).

Table 3. Significant Differences between Government and Government-Assisted Schools on Each of the Psychosocial Dimensions

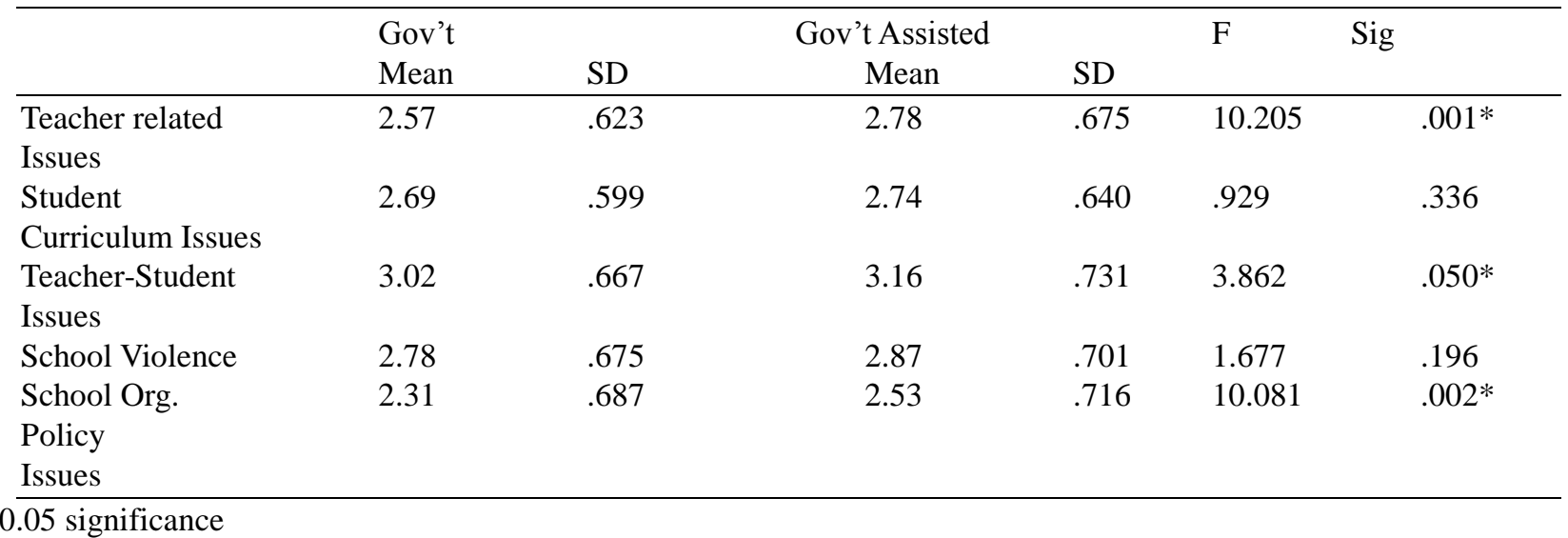

$\mathrm{P}<0.05$ significance

*significant at the 0.05 level

2(ii) Significant differences representing each of the psychosocial dimensions in urban and rural schools

There were significant differences representing each of the psychosocial dimensions in urban and rural schools (Table 4).

Table 4. Significant Differences in Each of the Psychosocial Dimensions in Urban and Rural Schools

\begin{tabular}{|c|c|c|c|c|c|c|}
\hline Dimensions & $\begin{array}{l}\text { Rural } \\
\text { Mean }\end{array}$ & $\mathrm{SD}$ & $\begin{array}{l}\text { Urban } \\
\text { Mean }\end{array}$ & SD & $\mathrm{F}$ & Sig \\
\hline $\begin{array}{l}\text { Teacher } \\
\text { Related } \\
\text { Issues }\end{array}$ & 2.83 & .638 & 2.62 & .671 & 12.270 & $.001 *$ \\
\hline $\begin{array}{l}\text { Student } \\
\text { Curriculum } \\
\text { Issues }\end{array}$ & 2.84 & .567 & 2.64 & .656 & 12.339 & $.000 *$ \\
\hline $\begin{array}{l}\text { Teacher- } \\
\text { Student } \\
\text { Issues }\end{array}$ & 3.23 & .778 & 3.02 & .650 & 10.110 & $.002 *$ \\
\hline $\begin{array}{l}\text { School } \\
\text { Violence }\end{array}$ & 2.97 & .663 & 2.73 & .702 & 11.455 & $.001 *$ \\
\hline $\begin{array}{l}\text { School } \\
\text { Org } \\
\text { Policy Issues }\end{array}$ & 2.58 & .702 & 2.37 & .710 & 10.182 & $.002 *$ \\
\hline PSE & 2.86 & .572 & 2.67 & .621 & 12.028 & $.001 *$ \\
\hline
\end{tabular}

$\mathrm{P}<0.05$ significance

*significant at the 0.05 probability level

2 (iii) Significant differences between Single sex and Co-ed schools

There were significant differences only in student curriculum issues (Table 5). 
Table 5. Significant Differences between Each of the PSE in Single Sex and Co-Ed Schools

\begin{tabular}{|c|c|c|c|c|c|c|}
\hline & Co-ed & & Same Sex & & & \\
\hline & Mean & SD & Mean & SD & $\mathrm{F}$ & $\mathrm{Sig}$ \\
\hline $\begin{array}{l}\text { Teacher } \\
\text { Related } \\
\text { Issues }\end{array}$ & 2.71 & .666 & 2.60 & .548 & .136 & .712 \\
\hline $\begin{array}{l}\text { Student } \\
\text { Curriculum } \\
\text { Issues }\end{array}$ & 2.73 & .626 & 2.00 & .000 & 6.842 & $.009 *$ \\
\hline $\begin{array}{l}\text { Teacher- } \\
\text { Student } \\
\text { Issues }\end{array}$ & 3.11 & .712 & 2.80 & .837 & .963 & .327 \\
\hline $\begin{array}{l}\text { School } \\
\text { Violence }\end{array}$ & 2.84 & .695 & 2.60 & .548 & .611 & .435 \\
\hline $\begin{array}{l}\text { School } \\
\text { Org } \\
\text { Policy Issues }\end{array}$ & 2.46 & .715 & 2.40 & .548 & .031 & .861 \\
\hline PSE & 2.75 & .608 & 2.40 & .548 & 1.682 & .195 \\
\hline
\end{tabular}

$\mathrm{P}<0.05$ significance

*significant at the 0.05 probability level

2 (iv) Significant differences in each of the psychosocial dimensions in small and large schools

There were significant differences found only in teacher-related issues (Table 6).

Table 6. Significant Differences between Each of the Psychosocial Dimensions in Small and Large Schools

\begin{tabular}{|c|c|c|c|c|c|c|}
\hline & Small & & Large & & & \\
\hline & Mean & SD & Mean & SD & $\mathrm{F}$ & Sig \\
\hline Teacher & 3.11 & .424 & 2.69 & .670 & 10.591 & $.001 *$ \\
\hline Related & & & & & & \\
\hline Issues & & & & & & \\
\hline Student & 2.74 & .594 & 2.73 & .623 & 0.015 & .904 \\
\hline Curriculum & & & & & & \\
\hline Issues & & & & & & \\
\hline Teacher- & 3.41 & .572 & 3.10 & .712 & 4.888 & .028 \\
\hline Student & & & & & & \\
\hline Issues & & & & & & \\
\hline School & 2.93 & .474 & 2.84 & .705 & .441 & .522 \\
\hline Violence & & & & & & \\
\hline School & 2.48 & .643 & 2.45 & .719 & .038 & .846 \\
\hline Org & & & & & & \\
\hline Policy Issues & & & & & & \\
\hline PSE & 2.89 & .506 & 2.74 & .613 & 1.461 & .227 \\
\hline
\end{tabular}

$\mathrm{P}<0.05$ significance

*significant at the 0.05 probability level

Research Question 3: What was the nature of the relationship between each of the five psychosocial dimensions?

The Pearson Moment Coefficient was the statistical used to measure the degree of relationship between the five psychosocial dimensions. There were moderate statistical significant correlations between the teacher-related issues and student curriculum issues $(r=.462, p>0.01)$, teacher-student issues $(r=.535, p>0.01)$, school violence and safety $(r=.621$, $\mathrm{p}>0.01)$, school organization and policy $(\mathrm{r}=.615, \mathrm{p}>0.01)$, student curriculum and student-teacher relationship ( $\mathrm{r}=.535$, $\mathrm{p}>0.01)$, and school violence and safety $(\mathrm{r}=.574, \mathrm{p}>0.01)$ (Table 7). 
Table 7. Significant Relationship between the Five Psychosocial Categories

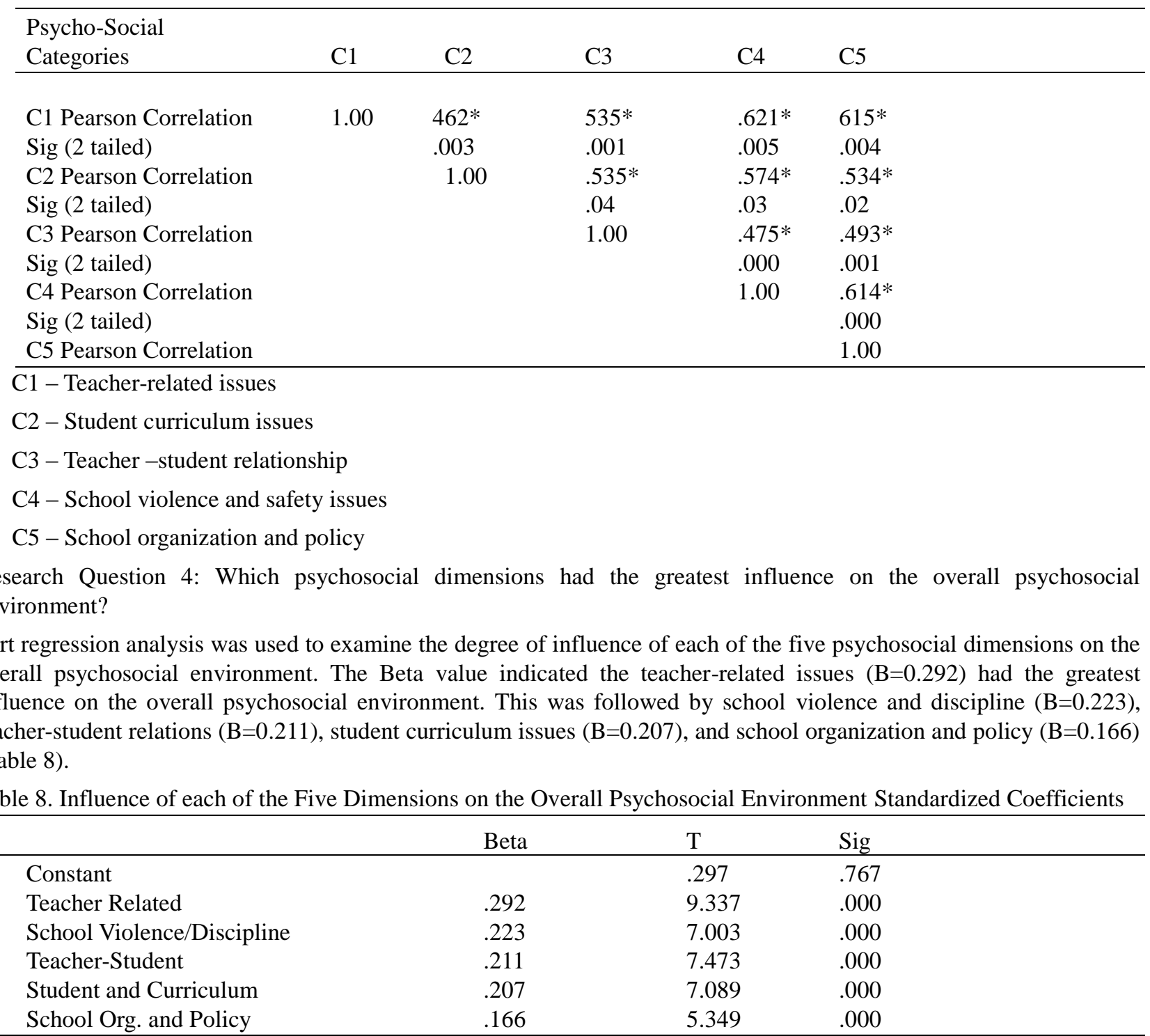

\section{Findings and Recommendations}

With regard to the placement of schools along a high-low psycho-social continuum, the findings suggested that approximately half of the schools in the sample had a moderate to high positive psycho-social environment while the other half had moderate to low negative environments. These findings suggested that some schools in the sample exhibited more positive, while others more negative psychosocial environments.

When the differences between the government and government -assisted schools were examined the findings suggested that the government assisted schools had more positive psycho-social environments in all five categories. One possible reason was the Concordat Agreement of 1960 between the State and the Denominational Boards. According to this Agreement, the Government assisted schools have an input in the appointment and transfer of teachers. Many theorists have contended that in government- assisted schools there is a more disciplined climate, greater homogeneity and open communication patterns between teachers that lead to a more positive PSE environment (Lee, Dedrich \& Smith, 1991).

There appeared to be no difference in the psycho-social environment when single and co-ed schools were compared. However, urban and rural as well as large and small schools, when compared, showed significant differences in the five psycho-social categories. Schools in the more rural areas and those with a small size tended to have more positive psycho -social environments. It is argued that the smaller size of rural schools allowed greater informal interaction among students, teachers and the community that leads to more positive relationships (Haughley \& Murphy, 1989).

The findings also suggested that there was a positive significant correlation among the five psycho-social categories. These positive correlations between the five categories suggested that teachers gave great recognition to the relationship 
between good school discipline, safety and security and effective school organization and policy in sustaining a healthy school environment

With regard to the strength of influence of the five categories on the overall psycho-social environment, Teacher-Related influence was greatest. This suggested that teachers viewed their professional relationship with others with mutual respect, sense of well-being and a sense of efficacy.

It is recommended that:

Greater attention should be given by the authorities to the psychosocial environments in the larger urban government schools especially in areas such as school discipline, teacher-related issues and organizational policy.

$>\quad$ There is an urgent need for active partnership and collaboration between the home, school and community to assess, identify and make changes that are integral to the improvement of physical, social and mental well-being of students.

$>\quad$ 'At risk' students, especially in government schools, should be tracked from pre-school onwards so that the necessary intervention strategies such as anger management, conflict resolution can help reduce incidences of school violence.

$>\quad$ With regard to student dietary health practices there is need for a coordinated multilevel approach including nutrition education, physical education, and parental involvement along with policies and modification in food services.

$>$ Further research is needed to collect more in-depth data on psychosocial processes to help develop theoretical models with regard to behavioural and other psycho social adjustment outcomes in students.

\section{References}

Baker, J.A., Dolly, L.J., Aupperlee, J.L., \& Patil, S.A. (2003). School Psychology Quarterly, 18 (2), 206-221. http://dx.doi.org/10.1521/scpq.18.2.206.21861

Bauman, S. (2008). The role of elementary school counselors in reducing school bullying. The Elementary School Journal, 108 (5), 362-375. http://dx.doi.org/10.1086/589467

Barth, J. M., Dunlap, S. I., Dane, H; Lochman, J.E., \& Wells, K.C. (2004). Classroom environment influences on aggression, peer relations, and academic focus. Journal of School Psychology, 42, 115-133. http://dx.doi.org/10.1016/j.jsp.2003.11.004

Bond,L., Butler,H., Glover,S., Godfrey,C., Patton,G (2001). Building capacity in schools: lessons from the Gatehouse Project: Approaches to health promotion in Australia. Health Education and Behaviour, 28(3), 368-383. http://dx.doi.org/10.1177/109019810102800310

Borg. W.R., \& Gall, M.D. (2000). Educational research: an introduction. New York: Longman.

Cartland, J., \& Ruch-Ross, H.S. (2006). Health behavior of school-age children: Evidence from one large city. Journal of School Health, 76 (5), 175-180. http://dx.doi.org/10.1111/j.1746-1561.2006.00091.x

Chomitz, K., Bays, P. \& Thomas, T.S. (2005). Quantifying the rural-urban gradient in Latin America and the Caribbean. World Bank Policy Research Working Paper No. 3634. Available at: http://ssrn.com/abstract=757164

Coladarci, T. (1992). Teachers' sense of efficiency and commitment to teaching. Journal of Experimental Education, 60 , 323-337. http://dx.doi.org/10.1080/00220973.1992.9943869

Creswell, J.W. (2008). Educational research. Pearson Education, Inc., New Jersey.

Deosaran, R. (2004). Benchmarking violence and delinquency in the secondary school. Towards a culture of peace and civility. Ministry of Education, Government of the Republic of Trinidad and Tobago.

Food and Agricultural Organization (FAO) 2003). World programme for the Census of Agriculture 2010: a system of integrated agricultural census and surveys. Rome, Italy.

Finley, L. L. (2003). Teachers' perceptions of school violence: A case study, Journal of School Violence, 2(2), 51-66. http://dx.doi.org/10.1300/J202v02n02_04

Flannery, D., Waster, K.L., \& Singer, M.L. (2004). Impact of exposure to violence in schools on child and adolescent mental health and behavior. Journal of Community Psychology, 32(5), 559-573. http://dx.doi.org/10.1002/jcop.20019

Fuller, B., Dauter, L., Hosek, A., Kirshenbaum., Mc Koy, D., Rigby, J., \& Vincent, J. M. (2009). Building Schools, 
rethinking quality. Early lessons from Los Angeles. Journal of Administration Education, 47(3), 336-349. http://dx.doi.org/10.1108/09578230910955773

Gadeyne, E. G., \& Onghena, P (2006). Psychosocial educational effectiveness criteria and that relation to teaching in primary education. School Effectiveness and School Improvement, 17(1), 63-85. http://dx.doi.org/10.1080/09243450500391573

Gadin, K., \& Hammarstom, A. (2003). Do changes in the psychosocial school environment influence pupils' health development? Results from a three-year follow-up study. Scandinavian Journal of Public Health, 31, 169-177. http://dx.doi.org/10.1080/14034940210134121

Gilman, R., \& Huebner, S. (2003). A review of life satisfaction research with children and adolescents. School Psychology Quarterly, 18, 192-205. http://dx.doi.org/10.1521/scpq.18.2.192.21858

Gowrie, G., Ramdass, M., Bowrin, C., \& Alleyne, G. (2009). A study of teachers' perception of school health in one educational district in Trinidad and Tobago. Paper presented at Biennial Conference, School of Education, The University of West Indies; Barbados. June 23-25.

Griffith, J. (1998). The relation of school structure and social environment in elementary schools. The Elementary School Journal, 99 (1), 54-80. http://dx.doi.org/10.1086/461916

Guskey, R. (1998). Teacher efficacy, self concept and attitudes toward the implementation of instructional innovation. Teaching and Teacher Education, 4, 63-69. http://dx.doi.org/10.1016/0742-051X(88)90025-X

Haughley, L. M., \& Murphy, P. L. (1989). Are rural teachers satisfied with the quality of their work life? Education, 104(1).

Havlinova, M., \& Schneidrova, D. (1995) Stress characteristics in school children related to different educational strategies and school climates. Central European Journal of Public Health, 3 (4), 205-209.

Henderson, A.T. (1998).Parents are school's best friends. Phi Delta Kappan, 70(2), 148-153.

Jordan, JL., Kostandini, G., \& Mykerezi, E. (2012). Rural and urban high school dropout rates :are they different? Journal of Research on Rural Education, 27(12), 1-21.

Kershaw, C., Blank, M.A., Bellon, J., \& Brian, D. (1994). Teachers' perceptions about their quality of school life according to their school setting, gender and years of teaching experience. American Educational Research Association. New Orleans, Louisiana. ( ERIC Documentation Reproduction Service: ED 373048).

Knuver, A. W. M., \& Brandsma, H.P. (1993). Cognitive and affective outcomes in school effectiveness research. School effectiveness and School Improvement, 4, 189-204. http://dx.doi.org/10.1080/0924345930040302

Lee, V.G., Dedrich, R.F., \& Smith, J.B. (1991). The effect of the social organization on teachers' efficacy and satisfaction. Sociology of Education, 64, 190-208. http://dx.doi.org/10.2307/2112851

Mac Phail-Wilcox, B., \& Hyler, L.R. (1988). Improving the Q.W.L. for teachers. A contingency approach. Journal of Research and Development in Education, 18(3).

Ministry of Education (1960). The Concordat of 1960. Retrieved 10.01.14 from http://nalisgov.tt/search/subjectguide/Legislation/the concordatof1960/tablid/3

Ministry of Education (1994). Report on the National Task Force on Education (1993-1994). Port of Spain, Trinidad and Tobago.

Morrison, G. M., Furlong, M. J., \& Morrison, R. L. (1994). School violence to school safety: reforming the issue for school psychologists. School Psychology Review, 23 (2), 236-250.

Nutbeam., D, Smith C., Moore, L., \& Bauman, A. (1993). Warning! Schools can damage your health: alienation from school and its impact on health behaviours. Journal of Pediatrics and Child Health, 29, Suppl.1: s, 25-30. http://dx.doi.org/10.1111/j.1440-1754.1993.tb02256.x

Olweus, D. (March 2003). A profile of bullying. Educational Leadership, 60 (6), 12-22.

Onafowora, L.L. (2004). Teacher efficiency issues in the practice of novice teachers. Educational Research Quarterly, $28,34-43$.

Patton, G. C., Glover, S., Bond, L., Butler, H., Godrey, C., Di Pietro, G., \& Bowes, G. ( 2000).The Gatehouse project: A systematic approach to mental health in secondary schools in Australia and New Zealand. Journal of Psychiatry, 34(4), 586-593.

Ryan, J. (2002). Promoting inclusive school - communing relationships. Administrator strategies for overpowering and 
enabling parents in diverse contexts. Journal of Teaching and Learning, 2(1), 1-19.

Schaeffer, S. (1999). A framework for rights-based, child-friendly schools. UNICEF, New York.

Semke, C.A. \& Sheridan, S.M. (2011). Family school connections in rural educational settings: a systematic review of the empirical literature. Retrieved from the National Center for research on Rural Education website: http://r2ed.unl.edu

Skevington, S. \& Puitandy, M. (2003). Creating an environment of emotional and social well-being :An important responsibility for a health promoting and child-friendly school. WHO/UNECEF.

Sprague, J., Nishioka, V., \& Smith, G. (2007). Safe schools positive behavior supports and mental supports: Lessons learned from three safe schools/healthy student communities. Journal of School Violence, 6(2), 93-116. http://dx.doi.org/10.1300/J202v06n02_06

Sirotnik, K. A. (1980). Psychometric implications of the unit of analysis problem. Journal of Educational Measurement, $248-84$.

Stephens, R. D. (1994). Planning for Safer and better schools: School violence prevention and intervention strategies. School Psychology Review, 23(20), 204-215.

Tanner, K. C. (2008). Explaining relationships among student outcomes and the school's physical environment. Journal of Advanced Academics, 19(3), 444-471.

Uline, C., \& Tschaumen-Moran, M. (2008). The walls speak: the interplay quality, facilities, school climate and student achievement. Journal of Educational Administration, 40(1), 55-73. http://dx.doi.org/10.1108/09578230810849817

Unesco (2000). The Dakar Framework for Action, Education for All: Meeting and collective commitments: World Education Forum. Dakar, Senegal, 26 -28 April.

Vamos, S. (2006). Creating a healthy school using the healthy school report card. Alexandria, Virginia, ASCD.

WHO (2000). Creating health - promoting schools. WHO/SCHOOL/00.3

\section{(c)) EY}

This work is licensed under a Creative Commons Attribution 3.0 License. 